\title{
Interferensi Sintaksis Bahasa Indonesia terhadap bahasa Jerman pada Schriftlicher Ausdruck dalam Matakuliah B1- Prüfüngsvorbereitung
}

\section{Indonesian Syntactic Interference toward German on Schriftlicher Ausdruck from the 1-Prüfüngsvorbereitung- Course}

\author{
Kirana Anjastya Prima Raymondra, Herri Akhmad Bukhori* \\ Universitas Negeri Malang, Jl. Semarang No. 5 Malang, Jawa Timur, Indonesia \\ *Penulis korespondensi, Surel: herri.akhmad.fs@um.ac.id
}

Paper received: 02-01-2021; revised: 15-01-2021; accepted: 30-01-2021

\begin{abstract}
Abstrak
Interferensi adalah kesalahan berbahasa berupa bercampurnya unsur bahasa pertama ke dalam bahasa kedua. Salah satu kesalahan tersebut seperti menulis kalimat bahasa kedua menggunakan aturan pembentukan kalimat bahasa pertama. Fenomena ini dibahas dalam sintaksis. Sintaksis merupakan cabang linguistik yang khusus membahas aturan penyusunan kata dan frasa untuk membentuk kalimat dengan susunan yang tepat. Penelitian ini bertujuan mengidentifikasi interferensi sintaksis bahasa Indonesia terhadap bahasa Jerman pada teks karangan schriftlicher Ausdruck yang diambil dari mata kuliah B1-Prüfungsvorbereitung. Keseluruhan karangan yang diteliti berjumlah 21 . Kalimat yang mengandung interferensi sintaksis bahasa Indonesia di data pada tabel dokumentasi dan dianalisis menggunakan teori kesalahan berbahasa oleh James dan Corder. Hasil penelitian menunjukkan terdapat seratus sepuluh data kalimat yang mengandung interferensi sintaksis bahasa Indonesia. Data tersebut dikelompokkan ke dalam error dan mistake. Data yang termasuk error yaitu interferensi urutan kata dalam kalimat, penanggalan unsur kalimat (subjek, pronomina refleksif, verba, konjungsi), penambahan unsur kalimat (preposisi), dan penggunaan unsur kalimat (konjungsi). Data yang termasuk mistake adalah interferensi penggunaan unsur kalimat (verba sesuai konteks kalimat, konjungsi, preposisi, adverbia, dan kata).
\end{abstract}

Kata kunci: interferensi, sintaksis, schriftlicher ausdruck

\begin{abstract}
Interference is a language error in the mixing of first language elements into the second language. One of the error types is composing a second language sentence using the structure of the first language. This phenomenon is discussed in syntax. Syntax is the linguistic branch that refers to the rules for arranging words and phrases to make a well-formed sentence. The purpose of this study is to identify Indonesian syntactic interference toward German on the texts Schriftlicher Ausdruck taken from the B1-Prüfungsvorbereitung-course. The total number of texts was 21. Sentences containing Indonesian syntactic interference were recorded in the documentation table and analyzed using the language error theory by James and Corder. The results showed that there are one hundred and tensentence data containing Indonesian syntactic interference. The data are grouped into error and mistake categories. The data that include errors are interference of word order in a sentence, omission of sentence elements (subject, reflexive pronoun, verbs, conjunction), the addition of sentence elements (preposition), and use of sentence element (conjugation). The data that include mistakes are interference of the use of sentence elements (verb according to the context of the sentence, conjunction, preposition, adverb, and word).
\end{abstract}

Keywords: interference, syntax, schriftlicher ausdruck 


\section{Pendahuluan}

Bahasa adalah alat komunikasi manusia. Manusia menggunakan bahasa, baik itu dalam bentuk lisan maupun tulis untuk menyampaikan gagasannya. Manusia dengan anugerah yang dimilikinya mampu menggunakan lebih dari satu bahasa, yaitu bahasa pertama dan bahasa kedua. Dalam kaitannya dengan proses pemerolehan bahasa kedua terdapat istilah interferensi. Menurut Nababan dalam Chaer dan Agustina (2010) interferensi merupakan kesalahan berbahasa yang terjadi akibat pengaruh bahasa atau dialek pertama.

Interferensi merujuk ke interaksi dua bahasa yang berkontak di waktu yang bersamaan (Parera, 1997). Kontak dua bahasa ini menyebabkan kekacauan pada penggunaan salah satu bahasa karena adanya pengaruh oleh bahasa lainnya. Meskipun dianggap sebagai kesalahan, tetapi interferensi adalah hal yang wajar terjadi di kalangan pemelajar bahasa kedua. Interferensi dapat terjadi pada beberapa cabang linguistik seperti fonologi, morfologi, dan sintaksis. Hal ini didukung oleh Ardila, Agustine dan Rosi (2018) bahwa interferensi merupakan sebuah kesalahan yang mencakup pelafalan bunyi yang dibahas pada cabang linguistik fonologi, kosakata pada morfologi, dan tata bahasa pada sintaksis.

Sintaksis merupakan cabang linguistik yang membahas konstruksi kebahasaan yang didasarkan pada kata (Arifatun, 2012). Hasanudin (2018) menambahkan, kajian yang dibahas dalam sintaksis yaitu bentuk, frasa, klausa, dan kalimat. Kata adalah satuan terkecil yang dapat mengisi fungsi sintaksis. Frasa juga dapat mengisi fungsi sintaksis, tetapi frasa terdiri dari lebih dari satu kata. Kata atau frasa berdiri berderet membentuk klausa, sehingga dapat diartikan klausa merupakan konstruksi yang di dalamnya terdapat kata atau frasa yang menempati fungsi-fungsi sintaksis. Klausa yang diakhiri dengan intonasi final disebut kalimat. Intonasi final tersebut seperti intonasi deklaratif (dalam ragam tulis berwujud tanda titik), intonasi interogatif (dalam ragam tulis berwujud tanda tanya), intonasi imperatif (dalam ragam tulis berwujud tanda seru), dan intonasi interjektif (dalam ragam tulis berwujud tanda seru) (Chaer, 2015).

Konsep dasar yang perlu dipahami dalam mempelajari sintaksis yaitu fungsi, kategori, dan peran sintaksis. Menurut Verhaar dan Chaer dalam Chaer (2015), fungsi sintaksis tersebut merupakan bagian-bagian kosong dalam struktur sintaksis yang akan diisi oleh kategori sintaksis. Yang termasuk ke dalam fungsi sintaksis yaitu subjek, predikat, objek, komplemen, dan keterangan. Dalam bahasa Jerman fungsi sintaksis terdiri dari Subjekt, Prädikat, Objekt, dan Adverbial. Contoh pada kalimat Ich lerne Mathematik 'Saya belajar matematika'. Pada kalimat tersebut terdapat fungsi subjek, predikat, dan objek. Setiap fungsi tersebut diisi oleh kategori sintaksis berupa kata. Dalam kalimat tersebut fungsi subjek diisi oleh kata ich 'saya' yang berkategori nomina (Nomen). Fungsi predikat diisi oleh kata lerne 'belajar' yang berkategori verba (Verb). Fungsi objek diisi oleh kata Mathematik 'matematika' yang berkategori nomina. Di antara semua fungsi sintaksis tersebut, Chafe dalam Chaer (2015) menyatakan bahwa predikat adalah fungsi sintaksis yang berkedudukan sebagai pusat klausa. Artinya, predikat menentukan kehadiran fungsi sintaksis lainnya serta kategori yang mengisi fungsi sintaksis tersebut. Chaer (2015) menyebut hubungan antara predikat dengan fungsi serta kategori sintaksis yang dimunculkan ini dengan istilah peran sintaksis.

Sintaksis bahasa Indonesia dan sintaksis bahasa Jerman jelas memiliki perbedaan. Salah satu perbedaan itu dapat dilihat pada susunan kata (Wortstellung) dalam kalimat, terutama posisi verba yang berfungsi sebagai predikat. Contoh pada kalimat deklaratif (Aussagesatz) Um 
18.00 Uhr und 19.00 Uhr ich bete. Interferensi sintaksis terjadi pada posisi subjek dan predikat dalam kalimat. Dalam kalimat tersebut subjek ich terletak di posisi kedua setelah keterangan waktu um 18.00 Uhr und 19.00 Uhr. Konstruksi tersebut tidak berterima karena menurut sintaksis bahasa Jerman, verba menduduki posisi kedua dalam Aussagesatz, sehingga konstruksi yang benar adalah Um 18.00 Uhr und $19.00 \mathrm{Uhr}$ bete ich.

Kesalahan berbahasa, salah satunya seperti contoh tersebut, merupakan hal yang wajar terjadi dalam pemerolehan suatu bahasa. James (dalam Adijaya, 2016) berpendapat kesalahan berbahasa adalah ketidaktepatan dalam menggunakan unsur-unsur bahasa. Corder dalam Parera (1997) membatasi istilah kesalahan berbahasa ke dalam mistake dan error. Istilah error dan mistake sekilas memiliki makna yang mirip, yaitu mengacu pada kesalahan. Namun, terkait dengan analisis kesalahan berbahasa kedua istilah ini memiliki makna yang berbeda. Mistake adalah jenis kesalahan berbahasa yang dipengaruhi oleh faktor kemampuan ingatan, mengeja dalam lafal, dorongan emosional, dan sebagainya. Error adalah kesalahan sistematis yang dilakukan secara konsisten dan menjadi ciri khas pemelajar bahasa. Sementara pengertian mistake dan error oleh Corder dideskripsikan berbeda oleh Indihadi (2015). Disebutkan bahwa mistake adalah kesalahan berbahasa yang diakibatkan oleh kesalahan pemilihan kata atau ungkapan untuk situasi tertentu. Error adalah kesalahan berbahasa yang berupa pelanggaran kaidah bahasa target.

James dalam Adijaya (2016) membagi kategori kesalahan berbahasa ke dalam dua kategori, yaitu: Linguistic category dan Surface structure. Linguistic category merupakan kesalahan berbahasa yang didasarkan pada tataran linguistik, seperti morfologi, sintaksis, dan lain-lain. Surface structure adalah identifikasi kesalahan berbahasa berdasarkan kesalahan konstruksi dalam penggunaan bahasa. Kesalahan tersebut dibedakan menjadi empat jenis, yaitu: (1) penghilangan unsur bahasa dalam kalimat (omission), (2) penambahan unsur bahasa dalam kalimat (addition), (3) ketidaktepatan pembentukan kata dalam kalimat (misformation), dan (4) ketidaktepatan menyusun kata-kata dalam kalimat (misordering).

Penelitian ini difokuskan pada interferensi sintaksis bahasa Indonesia yang terkandung dalam teks berbahasa Jerman. Teks tersebut diambil dari mata kuliah B1Prüfüngsvorbereitung. Matakuliah ini merupakan matakuliah yang disajikan untuk mengasah empat keterampilan berbahasa Jerman mahasiswa sebagai persiapan untuk mengikuti tes kemahiran berbahasa Jerman secara mandiri (selbständige Sprachverwendung) setara tingkat B1. Materi matakuliah ini meliputi informasi mengenai tes tersebut dan juga latihan-latihan untuk mengasah keterampilan berbahasa yang meliputi: latihan membaca (Leseverstehen), latihan menyimak (Hörverstehen), latihan menulis (Schriftlicher Ausdruck) dan tata bahasa (Sprachbausteine), dan latihan berbicara (Mündlicher Ausdruck) (Katalog Jurusan Sastra Jerman, 2018). Teks yang diambil adalah teks schriftlicher Ausdruck yang terdiri dari tiga bagian, yaitu Aufgabe 1, Aufgabe 2, dan Aufgabe 3. Penelitian ini bertujuan untuk mengidentifikasi interferensi sintaksis bahasa Indonesia yang muncul pada teks tersebut.

\section{Metode}

Dalam penelitian ini digunakan metode penelitian kualitatif deskriptif. Penelitian kualitatif deskriptif adalah penelitian yang berusaha mendeskripsikan sebuah objek atau peristiwa secara alamiah atau apa adanya (Mukhtar, 2013). Sumber data penelitian ini diambil di kelas B1-Prüfungsvorbereitung Offering A yang disajikan di semester genap tahun akademik 2019/2020. Perkuliahan ini berlangsung di gedung A2 lantai 1 ruang 8, Fakultas Sastra, 
Universitas Negeri Malang. Subjek penelitian ini adalah mahasiswa pada perkuliahan tersebut dan berperan sebagai pemberi informasi yang dibutuhkan untuk keperluan penelitian (Mukhtar, 2013). Mahasiswa di kelas ini berjumlah 23 orang, terdiri dari 21 mahasiswa angkatan 2018 dan dua mahasiswa angkatan 2015. Dari 23 mahasiswa, berhasil dikumpulkan 21 karangan schriftlicher Ausdruck sebagai sumber data. Setiap karangan berisi terdiri dari tiga bagian, yaitu Aufgabe 1, Aufgabe 2, dan Aufgabe 3. Pada Aufgabe 1 mahasiswa harus membuat sebuah email pribadi (persönliche Email) berdasarkan situasi dan poin-poin bahasan (Leitpunkte) yang telah ditentukan untuk dituangkan ke dalam persönliche Email tersebut. Kata yang harus ditulis berjumlah sekitar delapan puluh dan dikerjakan dalam waktu maksimal dua puluh menit. Pada Aufgabe 2 mahasiswa harus membuat sebuah teks opini pendek yang terdiri dari sekitar delapan puluh kata. Teks opini tersebut ditulis berdasarkan sebuah tema diskusi online. Untuk menyelesaikan Aufgabe 2 diberikan waktu maksimal 25 menit. Pada Aufgabe 3 mahasiswa harus membuat email setengah resmi (halbformelle Email) yang terdiri dari 45 kata. Isi halbformelle Email ini berdasarkan situasi dan Leitpunkte yang telah ditentukan. Waktu yang disediakan adalah lima belas menit.

Data penelitian ini berupa kalimat pada teks tersebut yang mengandung interferensi sintaksis bahasa Indonesia. Data dianalisis dengan menggunakan instrumen penelitian. Instrumen penelitian adalah alat yang digunakan untuk melaksanakan proses pengumpulan data penelitian guna mendapatkan hasil yang lebih baik (Arikunto, 2010). Dalam penelitian ini digunakan dua instrumen, yaitu instrumen utama dan instrumen pendukung. Instrumen utama adalah peneliti sendiri (Ghony \& Almanshur, 2012), sedangkan instrumen pendukung berupa tabel dokumentasi. Tabel dokumentasi berfungsi sebagai alat untuk mendata kalimat bahasa Jerman yang mengandung interferensi sintaksis bahasa Indonesia. Berikut adalah tabel dokumentasi pada penelitian ini:

Tabel 1. Tabel Dokumentasi

Interferensi:

\begin{tabular}{|c|c|c|c|c|}
\hline No. Data & Kode Data & Kalimat Interferensi & Koreksi & Keterangan \\
\hline 1 & & & & \\
\hline 2 & & & & \\
\hline 3 & & & & \\
\hline
\end{tabular}

Keterangan:

Interferensi : Kategori interferensi $\begin{array}{ll}\text { Kode Data } & \text { Inisial nama lengkap penulis kalimat yang mengandung interferensi dan urutan } \\ & \text { kalimat tersebut dalam teks. Contoh: Interferensi ditemukan pada teks Aufgabe } 1\end{array}$ (informelle Email) pada kalimat ketiga yang ditulis oleh subjek penelitian bernama Dinie Dwi Putri. Berdasarkan temuan tersebut kode data ditulis DDP3

Kalimat Interferensi : Kalimat bahasa Jerman yang mengandung interferensi sintaksis bahasa Indonesia

Koreksi

: Perbaikan kalimat yang disarankan berdasarkan sintaksis bahasa Jerman.

Keterangan

: Penjelasan kesalahan yang terdapat dalam kalimat

Dalam tahap penelitian, sumber data dibaca secara keseluruhan dan dianalisis berdasarkan sintaksis bahasa Jerman dan sintaksis bahasa Indonesia untuk mengetahui apakah suatu kalimat mengandung interferensi sintaksis bahasa Indonesia. Struktur kalimat yang mengandung interferensi sintaksis bahasa Indonesia dikumpulkan di tabel dokumentasi. Kemudian data tersebut dianalisis dengan teori kesalahan berbahasa dari James dan Corder. James dalam Adijaya (2016) mengelompokkan kesalahan berbahasa ke dalam: (1) penghilangan unsur bahasa dalam kalimat (omission), (2) penambahan unsur bahasa dalam kalimat (addition), (3) ketidaktepatan pembentukan kata dalam kalimat (misformation), dan (4) ketidaktepatan menyusun kata-kata dalam kalimat (misordering). Corder dalam Parera 
(1997) membagi kesalahan berbahasa ke dalam error dan mistake. Pertama, data dikumpulkan ke dalam table dokumentasi berdasarkan jenis interferensinya apakah termasuk ke dalam omission, addition, misformation, atau misordering. Kemudian data tersebut dikelompokkan lagi kedalam error dan mistake. Analisis data tersebut kemudian diserahkan kepada triangulator ahli untuk dikoreksi. Kemudian peneliti memperbaiki analisis data berdasarkan koreksi dan mendiskusikannya dengan triangulator ahli. Setelah data dinyatakan valid, data dipaparkan secara deskriptif. Deskripsi tersebut berupa penjelasan interferensi yang terdapat dalam kalimat serta perbaikan kalimat yang dapat disarankan.

\section{Hasil dan Pembahasan}

Berdasarkan analisis data, ditemukan interferensi sintaksis bahasa Indonesia pada teks schriftlicher Ausdruck di setiap bagian, yaitu Aufgabe 1, Aufgabe 2, dan Aufgabe 3. Data dikelompokkan menggunakan teori kesalahan berbahasa oleh James (dalam Adijaya, 2016). Bentuk kesalahan tersebut, yaitu: (1) penghilangan unsur bahasa dalam kalimat (omission), (2) penambahan unsur bahasa dalam kalimat (addition), (3) ketidaktepatan pembentukan kata dalam kalimat (misformation), dan (4) ketidaktepatan menyusun kata-kata dalam kalimat (misordering). Selanjutnya data akan digolongkan ke dalam error atau mistake menggunakan teori kesalahan berbahasa dari Corder yang dipaparkan oleh Indihadi (2015). Error dijelaskan sebagai kesalahan berbahasa berupa penyimpangan kaidah bahasa dan mistake dimaknai sebagai kesalahan akibat ketidaktepatan pemilihan kata atau ungkapan. Berikut adalah bentuk-bentuk interferensi tersebut:

\subsection{Bentuk Interferensi Sintaktis Bahasa Indonesia pada schriftlicher Ausdruck}

\section{Interferensi Urutan Kata dalam Kalimat}

Urutan kata adalah posisi kata dalam konstruksi sintaksis (Chaer, 2015). Kata dalam kalimat harus disusun sesuai sintaksis bahasa sasaran. Penempatan posisi kata yang tidak sesuai kaidah sintaksis bahasa sasaran menyebabkan kalimat tidak berterima. Terdapat perbedaan aturan penempatan kata dalam kalimat menurut sintaksis bahasa Indonesia dan bahasa Jerman. Chaer (2015) menjelaskan bahwa dalam kalimat bahasa Indonesia posisi subjek selalu mendahului predikat dan predikat selalu mendahului objek, sedangkan dalam bahasa Jerman subjek tidak harus selalu mendahului predikat dan predikat tidak selalu mendahului objek. Aturan yang berlaku menurut sintaksis bahasa Jerman adalah predikat terletak di posisi kedua, seperti pada Aussagesatz (Homberger \& Madsen, 1988).

Dari keseluruhan seratus sepuluh data ditemukan tiga puluh data interferensi urutan kata dalam kalimat. Kebanyakan interferensi urutan kata dalam kalimat terjadi pada urutan kata yang menduduki fungsi subjek dan predikat. Fungsi subjek diisi oleh nomina, sedangkan predikat diisi oleh verba. Pada data yang mengandung interferensi ini, subjek selalu diletakkan mendahului verba, sehingga letak verba dalam kalimat bahasa Jerman tersebut tidak terletak di posisi kedua, melainkan ketiga. Contoh pada kalimat Maria, nächstes Jahr ich möchte nach italien fliegen (MRA13). Posisi pertama diisi oleh keterangan waktu nächstes Jahr, sehingga jika aturannya verba harus diletakkan di posisi kedua, seharusnya posisi setelah keterangan waktu diisi oleh Modalverb möchte. Jika setelah keterangan waktu diisi oleh subjek ich, kalimat tersebut berarti telah terpengaruh oleh konstruksi kalimat bahasa Indonesia yang menempatkan subjek mendahului predikat. Kalimat tersebut seharusnya ditulis Maria, nächstes Jahr möchte ich nach Italien fliegen. 
Selain itu, interferensi penempatan subjek yang selalu mendahului predikat juga muncul pada Nebensatz. Contoh pada kalimat Ich kann nicht zur goldenen Hochzeit kommen, weil ich habe ein anderes Termin (UHA5). Menurut sintaksis bahasa Jerman, pada Nebensatz yang menggunakan subordinierende Konjunktionen, seperti dass, weil, dan wenn, verba harus diletakkan di akhir kalimat (Pittner \& Berman, 2008). Nebensatz pada contoh tersebut menggunakan konjungsi weil, sehingga verba habe seharusnya diletakkan di akhir kalimat. Verba habe yang diletakkan setelah subjek ich terpengaruh oleh konstruksi kalimat bahasa Indonesia yang menyatakan bahwa subjek selalu mendahului predikat. Kalimat tersebut juga mengandung kesalahan yang berkaitan dengan Kasus pada konstruksi ein anderes Termin. Haben merupakan verba yang diikuti Kasus Akkusativ. Termin merupakan nomina berartikel der, sehingga konstruksi yang tepat adalah einen anderen Termin. Berdasarkan penjelasan itu, kalimat tersebut seharusnya ditulis Ich kann nicht zur goldenen Hochzeit kommen, weil ich einen anderen Termin habe.

\subsubsection{Interferensi Penanggalan Unsur Kalimat}

Interferensi Penanggalan Subjek

Subjek merupakan unsur kalimat yang paling sering muncul yang menyertai verba dan berkasus Nominativ (Pittner \& Berman, 2008). Subjek juga merupakan fungsi sintaksis yang berkategori nomina. Pada penelitian ini ditemukan tiga data yang mengandung interferensi penanggalan subjek. Subjek ditiadakan karena penggunaan jenis kata dalam bahasa Indonesia selain nomina dianggap dapat berfungsi sebagai subjek. Jenis kata tersebut, yaitu adverbia meistens yang muncul pada kalimat Aber meistens sehen Videos im Internet (ZSR7). Meistens merupakan adverbia sehingga tidak dapat berfungsi sebagai subjek, sehingga harus diganti dengan nomina untuk mengisi peran subjek, seperti Mädchen. Oleh sebab itu, koreksi untuk kalimat tersebut adalah Aber Mädchen sehen meistens Videos im Internet.

Selain itu subjek yang biasanya ditiadakan berupa nomina yang berkategori kata ganti, yaitu es. Es merupakan kata ganti untuk nomina berartikel das. Selain itu, pronomina es juga berfungsi untuk mewakili suatu keadaan atau hanya menjadi unsur kalimat tanpa memiliki makna. Kehadiran es juga terikat oleh verba tertentu dalam sebuah konstruksi, contoh jemandem geht es irgendwie yang digunakan untuk menggambarkan keadaan seseorang (Langenscheidt Großwörterbuch: Deutsch als Fremdsprache, 2015). Interferensi penanggalan es dapat dilihat pada kalimat Ich hoffe, dass dir gut geht (BNAA2). Struktur kalimat tersebut tidak berterima karena kalimat tidak memiliki subjek es. Karena sifatnya yang sering tidak memiliki makna dalam kalimat, kehadirannya sering dilupakan oleh pemelajar bahasa Jerman (Kars \& Häussermann, 1992). Perbaikan untuk kalimat tersebut adalah Ich hoffe, dass es dir gut geht.

\section{Interferensi Penanggalan Pronomina Refleksif}

Dalam bahasa Jerman ada kelompok verba yang memerlukan pronomina refleksif (Reflexivpronomen). Dalam penelitian ini ditemukan tujuh data yang tidak disertai Reflexivpronomen pada kalimat padahal kata ganti tersebut diperlukan. Ketiadaan Reflexivpronomen terjadi karena terpengaruh oleh sintaksis bahasa Indonesia. Pada kasus ini ditemukan pada kalimat yang mengandung verba interessieren, treffen, dan bedanken. Ketika verba tersebut muncul dalam kalimat maka harus disertakan pula kata ganti refleksif yang sesuai dengan subjek. Contoh pada kalimat Ich möchte bei Ihnen für die Einladung bedanken (MFW3). Predikat kalimat tersebut berupa verba bedanken yang wajib diikuti oleh Reflexivpronomen im Akkusativ. Reflexivpronomen tersebut diletakkan setelah Modalverb 
möchte, sehingga kalimat tersebut seharusnya menjadi Ich möchte mich bei Ihnen für die Einladung bedanken. (MFW3)

\section{Interferensi Penanggalan Verba}

Ketiadaan verba dalam kalimat bahasa Jerman juga terpengaruh oleh sintaksis bahasa Indonesia. Dalam kasus ini ditemukan sebanyak delapan belas data dari seratus sepuluh data. Verba yang ditiadakan tersebut kebanyakan berupa Copula Verb. Pittner dan Berman (2008) menerangkan bahwa Kopulaverb merupakan verba yang berfungsi membentuk predikat dengan jenis kata lain, seperti adjektiva dan nomina. Hal tersebut berdasarkan penjelasan Pittner dan Berman (2008:20) „Sie bilden das Prädikat zusammen mit anderen Elementen wie Adjektivphrasen, Nominalphrasen im Nominativ,... Durch diese erhält das Prädikat erst seine volle Bedeutung." Pittner dan Berman menjelaskan Kopulaverben membentuk predikat bersama dengan elemen lainnya seperti frasa adjektival dan frasa nominal. Dengan ini (Kopulaverben) predikat dapat memiliki makna. Dari teori tersebut diketahui bahwa jika sebuah kalimat bahasa Jerman memiliki adjektiva atau nomina sebagai predikat, maka penyusunannya harus disertai dengan Kopulaverb, misalnya konstruksi Meine Mutter ist schön. Schön merupakan adjektiva yang menjelaskan subjek meine Mutter. Pada kalimat tersebut untuk menghubungkan meine Mutter dan schön harus digunakan ist yang merupakan Kopulaverb. Hal ini berbeda dengan sintaksis bahasa Indonesia. Kalimat tersebut jika ditransfer ke bahasa Indonesia menjadi ibu saya cantik. Dapat dilihat, untuk membentuk kalimat tersebut tidak diperlukan verba. Kalimat yang memiliki predikat berupa adjektiva dapat dibentuk tanpa adanya Kopulaverb (Chaer, 2015). Dengan demikian, kalimat Natürlich der Unterricht in diesem Kurs schwierig für mich, weil ich kein Basic habe (WA8) tidak berterima karena keberadaan adjektiva schwierig sebagai predikat tidak disertai dengan Kopulaverb. Kalimat tersebut seharusnya ditulis Natürlich ist der Unterricht in diesem Kurs schwierig für mich, weil ich keine Basis habe.

\section{Interferensi Penanggalan Konjungsi}

Pada penelitian ini ditemukan sebanyak empat belas data interferensi penanggalan konjungsi dalam kalimat. Kalimat tersebut berupa kalimat yang mengandung verba hoffen, sagen, wünschen, dan lain-lain. Kalimat dengan verba hoffen, sagen, wünschen biasanya terdiri dari Hauptsatz dan Nebensatz. Nebensatz ini berfungsi menjelaskan isi dari Hauptsatz. Untuk itu, konjungsi yang paling tepat digunakan adalah dass. Nebensatz ini disebut juga Inhaltsätze karena menerangkan isi pernyataan (Homberger \& Madsen, 1988), sehingga Hauptsatz dan Nebensatz pada kalimat (a) Ich hoffe, es geht dir gut (UHA2), (b) Ich hoffe, es geht Ihnen gut (UHA2), dan (c) Ich hoffe du kannst mit mir mitkommen (SSP10) seharusnya dihubungkan dengan konjungsi. Konjungsi yang tepat adalah dass karena berfungsi menerangkan isi Hauptsatz. Ketiadaan konjungsi pada kalimat-kalimat tersebut seperti pada ujaran dalam bahasa Indonesia 'Saya berharap kamu baik-baik saja', 'Saya berharap Anda baik-baik saja', dan 'Saya berharap kamu bisa ikut dengan saya' Kalimat tersebut dalam bahasa Indonesia ditulis tanpa konjungsi. Penggunaan dass menyebabkan verba diletakkan di akhir kalimat, sehingga perbaikan untuk kalimat tersebut (a) Ich hoffe, dass es dir gut geht, (b) Ich hoffe, dass es Ihnen gut geht, dan (c) Ich hoffe, dass du mit mir mitkommen kannst. 


\title{
3.1.3. Interferensi Penggunaan Unsur Kalimat
}

\author{
Interferensi Penggunaan Verba Sesuai Konteks Kalimat
}

Pemilihan verba dalam pembentukan kalimat bahasa Jerman seringkali dipengaruhi oleh hasil terjemahan harfiah dari bahasa Indonesia. Hal ini berpotensi menyebabkan verba menjadi kurang tepat jika digunakan dalam kalimat bahasa Jerman. Dari seratus sepuluh data ditemukan sebanyak lima data interferensi penggunaan verba dalam kalimat. Seperti pada data Die Unterricht des Kurs sehr interessant, weil mein Lehrer immer lachen macht (NVS7). Dalam kalimat tersebut interferensi muncul pada frasa verbal pada Nebensatz. Frasa verbal yang dimaksud adalah membuat tertawa, sehingga ditulislah dalam kalimat tersebut berupa terjemahan ke dalam bahasa Jerman, yaitu lachen machen, sedangkan dalam bahasa Jerman frasa verbal tersebut memiliki konstruksi tersendiri. Konstruksi tersebut yaitu jemandem zum lachen bringen, sehingga seharusnya kalimat tersebut ditulis Der Unterricht des Kurses ist sehr interessant, weil mein Lehrer uns immer zum Lachen bringt (NVS7).

\section{Interferensi Konjugasi Verba}

Pada interferensi konjugasi verba ditemukan sebanyak delapan belas data dari seratus sepuluh data. Pada kalimat ini bentuk verba berupa bentuk dasar, tidak dikonjugasikan atau diubah sesuai subjek kalimat. Ini seperti verba dalam kalimat bahasa Indonesia yang tidak berubah bentuk berdasarkan subjek kalimat. Konjugasi verba dalam bahasa Jerman sangat penting untuk menunjukkan subjek kalimat. Hal tersebut dijelaskan oleh Homberger dan Madsen (1988:44) “Wenn man ein Verb konjugiert, bildet man seine Personalformen; sie zeigen Person und Numerus an und sind meist an der Verb-Endung zu erkennen." Menurut penjelasan tersebut verba yang dikonjugasikan menunjukkan orang dan jumlah pelaku. Bentuk konjugasi tersebut dapat dilihat pada akhiran verba. Contoh pada kalimat Aber ich kann nicht kommen, weil ich nach Japan fliegen (MFW4). Interferensi dapat dilihat pada Nebensatz. Kalimat tersebut bersubjek ich, sehingga verba fliegen seharusnya dikonjugasikan dengan subjek ich menjadi fliege. Kalimat tersebut seharusnya menjadi Aber ich kann nicht kommen, weil ich nach Japan fliege.

\section{Interferensi Penggunaan Konjungsi}

Penggunaan konjungsi dalam kalimat bahasa Jerman juga terpengaruh oleh bahasa Indonesia. Dalam kasus ini ditemukan dua data dari seratus sepuluh data. Konjungsi yang dipilih merupakan hasil terjemahan dari bahasa Indonesia yang digunakan pada ragam nonformal, seperti konjungsi kalau yang digunakan untuk menggantikan konjungsi bahwa. Hal tersebut dapat dilihat pada data Ich habe gehört, wenn die Unterricht ist sehr schwierig (UHA11). Konjungsi wenn tidak tepat digunakan pada Nebensatz tersebut karena Nebensatz tersebut merupakan penjelasan isi dari Hauptsatz. Konjungsi yang tepat digunakan adalah dass, sehingga kalimat yang tepat adalah Ich habe gehört, dass der Unterricht sehr schwierig ist.

\section{Interferensi Penggunaan Preposisi}

Interferensi penggunaan preposisi muncul sebanyak sepuluh data dari seratus sepuluh data. Preposisi yang muncul seperti hasil terjemahan dari bahasa Indonesia, padahal dalam sintaksis bahasa Jerman, preposisi tersebut sudah ditentukan sesuai verba yang diiringinya. Dalam bahasa Jerman preposisi tersebut menempati fungsi sebagai Präpositionalobjekt (Homberger \& Madsen, 1988). Tugas preposisi ini adalah untuk menghubungkan nomina dengan kata lain yang muncul sebelumnya (Homberger \& Madsen, 1988). Interferensi muncul 
pada kalimat Ich gratuliere für Ihre goldenen Hochzeit (CPA2). Preposisi für tidak tepat berada di konstruksi kalimat tersebut karena dilihat dari verba gratulieren, preposisi yang tepat adalah zu. Konstruksi tersebut disebutkan dalam Langenscheidt Großwörterbuch: Deutsch als Fremdsprache (2015:499) (jemandem) (zu etwas) gratulieren, sehingga struktur kalimat yang tepat adalah Ich gratuliere Ihnen zu Ihrer goldenen Hochzeit (CPA2). Verba lainnya yang diikuti preposisi tertentu, yaitu verba interessieren diikuti preposisi für, verba denken diikuti preposisi $a n$, verba warten diikuti preposisi auf, dan lain-lain.

\section{Interferensi Penggunaan Adverbia}

Interferensi penggunaan adverbia muncul sebanyak empat data dari seratus sepuluh data. Penggunaan adverbia yang terpengaruh oleh bahasa Indonesia merupakan pemilihan adverbia yang tidak tepat disandingkan dengan kata lainnya dalam kalimat. Contoh pada data Der Kurs macht mir sehr Spaß,... (PW11). Adverbia sehr tidak tepat digunakan untuk menguatkan Spa $\beta$ karena $S p a \beta$ merupakan nomina. Adverbia sehr hanya digunakan untuk menguatkan adjektiva dan adverbia (Langenscheidt Großwörterbuch: Deutsch als Fremdsprache, 2015:991). Untuk menggantikan sehr, adverbia yang tepat digunakan adalah adverbia viel. Jadi, konstruksi kalimat yang benar adalah Der Kurs macht mir viel Spaß,...

\section{Interferensi Penggunaan Kata}

Interferensi penggunaan kata muncul sebanyak dua data dari seratus sepuluh data. Di antara data tersebut adalah penggunaan kata bahasa Indonesia yang digunakan dalam kalimat bahasa Jerman, seperti pada kalimat Am 17.Juli fliege ich nach Italia,... (GPZ4). Pada kalimat tersebut terdapat kata bahasa Indonesia, yaitu Italia. Selain itu juga penggunaan kata yang tidak sesuai seperti pada kalimat Ich bedanke mich für Ihre Einladung, es klingt spaß (PW1). Ketidaksesuaian kalimat tersebut ada konstruksi es klingt spa $\beta$. Verba klingt yang berasal dari klingen diikuti oleh adjektiva. Dalam penggunaannya dalam kalimat verba tersebut memiliki struktur etwas klingt irgendwie (Langenscheidt Großwörterbuch: Deutsch als Fremdsprache, 2015:641), sehingga tidak tepat jika verba klingt diikuti Spa $\beta$, karena Spa $\beta$ merupakan nomina. Kalimat tersebut seharusnya menjadi Ich bedanke mich für Ihre Einladung, es klingt toll!

\subsubsection{Interferensi Penambahan Unsur Kalimat}

\section{Interferensi Penambahan Preposisi}

Interferensi penambahan unsur kalimat terjadi pada penambahan preposisi dalam kalimat. Sebanyak dua belas data ditemukan dari seratus sepuluh data. Menurut Homberger dan Madsen (1988) Präpostion bertugas menghubungkan nomina dengan kata lain yang muncul sebelumnya. Penambahan preposisi dalam kalimat ini adalah sesuatu yang tidak perlu karena konstruksinya sudah ditetapkan. Penambahan preposisi pada data interferensi ini dimaksudkan untuk menghubungkan verba dengan nomina, sedangkan dalam bahasa Jerman terdapat verba yang langsung diikuti oleh objek tanpa diikuti preposisi. Seperti pada data $\mathrm{Am}$ ersten Tag lerne ich über kennenlernen mit ihm (PW10). Verba lernen tidak perlu diikuti preposisi sebelum objek, melainkan langsung diikuti objek Akkusativ, sehingga kalimat tersebut dapat diubah menjadi Am ersten Tag lerne ich das Thema Kennenlernen mit ihm.

\subsection{Kesalahan Berbahasa}

Berbagai bentuk interferensi sintaksis bahasa Indonesia tersebut di atas dikelompokkan ke dalam dua jenis kesalahan berbahasa. Klasifikasi jenis kesalahan berbahasa yang digunakan adalah teori dari Corder yang dipaparkan oleh Indihadi (2015). Error dijelaskan sebagai 
kesalahan berbahasa berupa penyimpangan kaidah bahasa dan mistake dimaknai sebagai kesalahan akibat ketidaktepatan pemilihan kata atau ungkapan.

\subsection{Error}

Corder dalam Indihadi (2015) menjelaskan bahwa error merupakan kesalahan berbahasa karena penutur melanggar aturan atau kaidah bahasa sasaran. Dalam kasus ini, mahasiswa melanggar kaidah bahasa Jerman yang disebabkan oleh faktor terbawanya kaidah sintaksis bahasa Indonesia pada teks yang diproduksi. Berdasarkan teori tersebut, interferensi yang termasuk ke dalam error adalah interferensi urutan kata dalam kalimat (misordering), interferensi penanggalan unsur kalimat (omission), interferensi penambahan unsur kalimat (addition), dan salah satu interferensi penggunaan unsur kalimat yaitu konjugasi.

Contoh interferensi urutan kata dalam kalimat dapat dilihat pada data (1) Maria, nächstes Jahr ich möchte nach italien fliegen (MRA13). Kalimat ini merupakan Aussagesatz dan ditemukan pada Aufgabe 1. Pelanggaran kaidah bahasa Jerman yang dilakukan adalah aturan penempatan verba dalam Aussagesatz. Dalam Aussagesatz verba diletakkan di posisi kedua dalam kalimat. Dalam kalimat tersebut yang berkategori verba adalah kata möchte. Kenyataannya, verba tersebut diletakkan di posisi ketiga. Posisi kedua yang dimaksud adalah posisi setelah keterangan waktu nächstes Jahr, sehingga perbaikan kalimat tersebut adalah Maria, nächstes Jahr möchte ich nach italien fliegen (MRA13). Selain karena melanggar kaidah bahasa Jerman, kesalahan ini disebut error juga karena merupakan kesalahan yang paling banyak muncul pada teks. Hal ini sesuai dengan pendapat Ellis dan Burkhuizen dalam Botley (2015) bahwa error merupakan kesalahan yang paling sering muncul dalam esai.

Interferensi penanggalan unsur kalimat meliputi penanggalan subjek, pronomina refleksif, verba, dan konjungsi. Penanggalan subjek ditemukan pada kalimat (4) Ich hoffe, dass dir gut geht (BNAA2). Kalimat ini terdapat pada Aufgabe 1. Pada konstruksi ini subjek es ditiadakan. Hal ini terjadi karena sifat es dalam konstruksi tersebut sering tidak memiliki makna dalam kalimat dan kehadirannya sering dilupakan oleh pemelajar bahasa Jerman (Kars \& Häussermann, 1992:119). Interferensi penanggalan pronomina refleksif seperti pada kalimat (8) Ich möchte bei Ihnen für die Einladung bedanken (MFW3). Kalimat ini terdapat pada Aufgabe 3. Kalimat ini melanggar kaidah bahasa Jerman, karena verba bedanken merupakan salah satu verba yang diikuti pronomina refleksif. Interferensi penanggalan verba terjadi pada kalimat (10) Natürlich ist der Unterricht in diesem Kurs schwierig für mich, weil ich keine Basis habe (WA8). Kalimat tersebut terdapat pada Aufgabe 1. Pada kalimat ini dihilangkan Kopulaverb sebagai unsur yang harus dihadirkan pada kalimat untuk membentuk predikat yang berkategori adjektiva. Kopulaverb ini seharusnya berada di posisi kedua dalam kalimat setelah adverbia natürlich dan sebelum frasa nominal der Unterricht. Interferensi penanggalan konjungsi muncul pada kalimat (12) Ich hoffe, es geht dir gut (UHA2). Pada kalimat ini penulis menanggalkan konjungsi dass yang harus ada untuk menghubungkan Hauptsatz dan Nebensatz yang menerangkan isi Hauptsatz.

Interferensi penambahan unsur kalimat dalam penelitian ini berupa penambahan preposisi yang seharusnya tidak perlu ada. Kesalahan ini dapat dilihat pada kalimat Am ersten Tag lerne ich über kennenlernen mit ihm (PW10). Kalimat ini ditemukan pada Aufgabe 1. Dalam kalimat tersebut yang disebut preposisi adalah über. Keberadaan über dalam kalimat tersebut merupakan sesuatu yang tidak perlu. Hal tersebut karena verba lernen tidak diikuti preposisi untuk menjelaskan objek yang dipelajari. 
Error juga ditemukan pada kesalahan konjugasi seperti pada kalimat (18) Aber ich kann nicht kommen, weil ich nach Japan fliegen (MFW4). Kalimat ini ditemukan pada Aufgabe 3. Verba fliegen tidak sesuai dengan kaidah bahasa Jerman karena kalimat tersebut bersubjek ich. Jika suatu kalimat bersubjek ich, bentuk verba harus berakhiran dengan - $e$.

\subsubsection{Mistake}

Mistake menurut Corder dalam Indihadi (2015) merupakan kesalahan bahasa yang diakibatkan oleh kesalahan pemilihan kata atau ungkapan sesuai situasi tertentu. Jenis kesalahan yang termasuk ini adalah interferensi penggunaan unsur kalimat, yang meliputi interferensi penggunaan verba sesuai konteks kalimat, preposisi, adverbia, dan kata.

Interferensi penggunaan verba yang tidak sesuai konteks kalimat dapat dilihat pada kalimat (15) Die Unterricht des Kurs sehr interessant, weil mein Lehrer immer lachen macht. (NVS7). Kalimat ini ditemukan pada Aufgabe 1. Penggunaan frasa verbal lachen machen merupakan terjemahan langsung dari bahasa Indonesia membuat tertawa. Frasa ini tidak tepat karena bahasa Jerman memiliki ungkapannya sendiri yaitu jemanden (mit etwas) zum Lachen bringen (Langenscheidt Großwörterbuch: Deutsch als Fremdsprache, 2015:687).

Interferensi penggunaan preposisi dapat dilihat pada kalimat (23) Und ich interessiere mich mit Italienisch (UHA7). Kalimat ini ditemukan pada Aufgabe 1. Pemilihan mit tidak tepat karena dalam bahasa Jerman verba interessieren berpasangan dengan preposisi für. Penggunaan mit seolah benar jika penyusunan kalimat tersebut berasal dari terjemahan langsung dari bahasa Indonesia tertarik dengan.

Interferensi penggunaan adverbia muncul pada kalimat Der Kurs macht mir sehr Spaß,... (PW11). Kalimat ini ditemukan pada Aufgabe 1. Adverbia sehr tidak tepat digunakan untuk menguatkan Spa $\beta$ karena Spa $\beta$ merupakan nomina. Adverbia sehr hanya digunakan untuk menguatkan adjektiva dan adverbia (Langenscheidt Großwörterbuch: Deutsch als Fremdsprache, 2015:991). Untuk menggantikan sehr, adverbia yang tepat digunakan adalah adverbia viel.

Interferensi penggunaan kata muncul pada kalimat Am 17.Juli fliege ich nach Italia,... (GPZ4). Kalimat ini terdapat pada Aufgabe 1. Kalimat tersebut mengandung kata bahasa Indonesia Italia. Selain itu juga penggunaan kata yang tidak sesuai seperti pada kalimat Ich bedanke mich für Ihre Einladung, es klingt spa $\beta$ (PW1). Kalimat ini terdapat pada Aufgabe 3. Ketidaksesuaian kalimat tersebut muncul pada konstruksi es klingt spa $\beta$. Verba klingt yang berasal dari klingen diikuti oleh adjektiva. Dalam penggunaannya dalam kalimat verba tersebut memiliki struktur etwas klingt irgendwie (Langenscheidt Großwörterbuch: Deutsch als Fremdsprache, 2015:641), sehingga tidak tepat jika verba klingt diikuti Spaß, karena Spa $\beta$ merupakan nomina.

\section{Simpulan}

Interferensi adalah kesalahan berbahasa berupa bercampurnya unsur bahasa pertama ke dalam bahasa kedua. Kesalahan tersebut disebabkan oleh penguasaan bahasa pertama yang lebih baik daripada bahasa kedua. Dalam penelitian ini, mahasiswa sebagai subjek penelitian lebih menguasai bahasa Indonesia daripada bahasa Jerman. Hal tersebut menyebabkan adanya pengaruh bahasa Indonesia terhadap penggunaan bahasa Jerman. Salah satu jenis kesalahan berbahasa yang ditemui yaitu kesalahan penyusunan kalimat. Aturan penyusunan kalimat dibahas pada sintaksis. Dalam penelitian ini diambil teks schriftlicher Ausdruck Aufgabe 1, 
Aufgabe 2, dan Aufgabe 3 dari mata kuliah B1-Prüfungsvorbereitung sebagai sumber data untuk diketahui adanya kalimat yang mengandung interferensi sintaksis bahasa Indonesia. Dari penelitian ini ditemukan seratus sepuluh data. Data tersebut berupa kalimat bahasa Jerman yang mengandung interferensi sintaksis bahasa Indonesia. Interferensi tersebut dikelompokkan ke dalam error dan mistake. Error adalah kesalahan berbahasa yang disebabkan oleh pelanggaran aturan atau kaidah bahasa sasaran. Data interferensi yang tergolong error yaitu interferensi urutan kata dalam kalimat, penanggalan unsur kalimat (subjek, pronomina refleksif, verba, konjungsi), penambahan unsur kalimat (preposisi), dan konjugasi. Mistake merupakan kesalahan bahasa yang diakibatkan oleh kesalahan pemilihan kata atau ungkapan sesuai situasi tertentu. Data yang termasuk mistake adalah interferensi penggunaan unsur kalimat (verba sesuai konteks kalimat, konjungsi, preposisi, adverbia, dan kata).

\section{Daftar Rujukan}

Adijaya, N. (2016). Kesalahan gramatikal pada teks materi ajar Bahasa Inggris yang dipergunakan Universitas Terbuka. Eduscience, 1(2).

Ardila, R.R., Agustine, A., \& Rosi, R. (2018). Analisis tingkat interferensi Bahasa Indonesia pada anak usia 12 tahun berdasarkan perbedaan latar belakang bahasa kedua orangtua. Parole Jurnal Pendidikan Bahasa dan Sastra Indonesia, 1(4), 35-44.

Arifatun, N. (2012). Kesalahan penerjemahan teks Bahasa Indonesia ke Bahasa Arab melalui Google Translate (Studi analisis sintaksis). Journal of Arabic Learning and Teaching, 2(1). Dari https://journal.unnes.ac.id/sju/index.php/laa/article/view/1506. Diakses 17 Februari 2020.

Chaer, A. \& Agustina, L. (2010). Sosiolinguistik: Perkenalan awal. Jakarta: Rineka Cipta.

Chaer, A. (2015). Sintaksis Bahasa Indonesia (Pendekatan Proses). Jakarta: Rineka Cipta.

Ghony, M.D.i \& Almanshur, F. (2012). Metodologi penelitian kualitatif. Jogjakarta: Ar-Ruzz Media.

Götz, D., dkk. (2015). Langenscheidt Großwörterbuch: Deutsch als Fremdsprache. München: Langenscheidt GmbH \& Co KG.

Hasanudin, C. (2018). Kajian sintaksis pada novel Sang Pencuri Warna karya Yersita. JPE (Jurnal Pendidikan Edutama), 5(2).

Homberger, D. \& Madsen, R. (1988). Übungen zur deutschen Grammatik. Frankfurt am Main: Diesterweg.

Indihadi, D. (2015). Analisisi kesalahan berbahasa. Dari http://file.upi.edu/Direktori/DUALMODES/PEMBINAAN_BAHASA_INDONESIA_SEBAGAI_BAHASA_KEDUA/10_BBM_8.pdf. Diakses 30 Agustus 2020.

Kars, J. \& Häussermann, U. (1992). Grundgrammatik Deutsch. Frankfurt am Main: Diesterweg.

Katalog Jurusan Sastra Jerman. (2018). Sastra Jerman Universitas Negeri Malang.

Mukhtar. (2013). Metode praktis penelitian deskriptif kualitatif. Jakarta: Referensi (GP Press Group).

Parera, J.D. (1997). Linguistik edukasional. Jakarta: Erlangga.

Pittner, K. \& Berman, J. (2008). Deutsche syntax. Tübingen: Narr. 